\title{
Fostering Written Production of Review TeXTS AMONG EFL UNIVERSITY STUDENTS Through a Genre-Based Approach
}

\author{
FOMENTO DE LA PRODUCCIÓN ESCRITA DE RESEÑAS ENTRE ESTUDIANTES UNIVERSitARIOS \\ DE ILE A TRAVÉS DE UN ENFOQUE BASADO EN EL GÉNERO
}

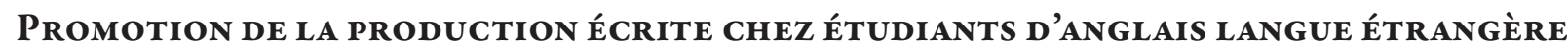
À L'ENSEIGNEMENT SUPÉRIEUR UNIVERSITAIRE À TRAVERS UNE APPROCHE PAR GENRES

Diana Carolina Durán-Bautista

M. A. in English Language Teaching

for Self-Directed Learning,

Universidad de La Sabana, Bogotá, Colombia.

Assistant Professor, Department of Foreign Languages and Cultures, Universidad de La Sabana, Bogotá, Colombia.

diana.duran2@unisabana.edu.co

https://orcid.

org/0000-0003-3957-7942

\begin{abstract}
This study investigated the effects of a Genre-Based Approach (GBA) on 54 participants' abilities to write a review text of a mobile application or website while reflecting on the "evaluating a text" function embedded in the target genre. The participants belonged to a pre-intermediate (A2.2 CEFR) EFL course offered at a university in Bogotá, Colombia that has implemented a GBA for over five years. The program recently adapted the teaching and learning cycle to give more prominence to the students' active participation in the Joint Construction phase by including systematic peer feedback with the further purpose of giving learners more independence from the teacher. The study aimed to assess the effects of the implementation on participants' written production and to explore their insights and awareness of the selected genre. Data were collected through students' artifacts, an online questionnaire, and focus groups, and were analyzed following a mixed-methods approach that incorporated grounded theory and descriptive statistics. Findings suggest an overall comprehension of the social purpose of the chosen genre, outstanding achievements of the task, a favorable acceptance of the implementation, and a perception of usefulness related to the peer feedback routines, although peer feedback was also considered the biggest challenge the participants faced.
\end{abstract}

Keywords: academic writing; EFL; systemic functional linguistics; genre-based approach; review text.

\section{RESUMEN}

El presente estudio investigó los efectos del enfoque basado en el género (GBA) en las habilidades de 54 participantes para escribir una reseña de una aplicación móvil o sitio web, mientras reflexionaban sobre la función "evaluar un texto" propia del género seleccionado. Los participantes asistían a un curso de inglés como lengua extranjera de nivel preintermedio (A2.2 CEFR), ofrecido por una universidad en Bogotá, Colombia, que ha implementado dicho enfoque durante más de cinco años. El programa adaptó recientemente el ciclo de enseñanza y aprendizaje de

Received: 2020-07-14 / Accepted: 2020-11-30 / Published; 2021-01-30

https://doi.org/10.17533/udea.ikala.v26n01a10 
forma que incluyera realimentación sistemática entre pares en la fase de construcción conjunta, con el doble propósito de dar más importancia a la participación activa de los estudiantes en esta etapa y de proporcionarles más independencia del profesor. El estudio tuvo como objetivo evaluar los efectos de la implementación en los productos escritos de los participantes y explorar sus percepciones y conocimiento del género seleccionado. Los datos se recopilaron a través de los trabajos de los estudiantes, un cuestionario en línea y grupos focales, y se analizaron siguiendo un método mixto que incorporaba la teoría fundamentada y la estadística descriptiva. Los hallazgos sugirieron una comprensión general del propósito social del género elegido, logros sobresalientes de la tarea, una aceptación favorable de la implementación y una percepción de utilidad relacionada con las rutinas de realimentación entre pares, aunque esta se consideró también como el mayor desafío enfrentado por los participantes.

Palabras clave: escritura académica; inglés como lengua extranjera; lingüística sistémico-funcional; enfoque basado en el género; reseñas.

\section{RÉSUMÉ}

La présente étude a examiné les effets de l'approche fondée sur le genre (GBA en anglais) sur les capacités de 54 participants pour rédiger un compte rendu d'une application mobile ou d'un site Web, tout en réfléchissant à la fonction «évaluer un texte » du genre choisi. Les participants étaient inscrits dans un cours d'anglais langue étrangère de niveau pré-intermédiaire (A2.2 CECR), offert par une université de Bogotá, en Colombie, qui avait déjà mis en œuvre cette approche depuis plus de cinq ans. Le programme a récemment adapté le cycle d'enseignement-apprentissage pour inclure un feedback systématique des pairs dans la phase de Construction Conjointe, dans le double but de donner plus d'importance à la participation active des étudiants à cette étape et de leur donner plus d'indépendance par rapport à l'enseignant. L'étude visait à évaluer les effets de la mise en œuvre sur les produits écrits des participants et à explorer leurs perceptions et leurs connaissances du genre choisi. Les données ont été recueillies à travers les travaux des étudiants, d'un questionnaire en ligne et de groupes de discussion, et elles sont analysées à l'aide d'une méthode mixte incorporant la théorie enracinée et la statistique descriptive. Les résultats suggèrent une compréhension générale du but social du genre choisi, des réalisations exceptionnelles de la tâche, une acceptation favorable de la mise en œuvre et une perception de l'utilité liée aux routines de feedback par les pairs, bien que cela ait également été considéré comme le plus grand défi rencontré par les participants.

Mots-clefs : écriture académique ; anglais langue étrangère ; linguistique fonctionnelle systémique; approche fondée sur les genres; comptes-rendus. 


\section{Introduction}

The English language is regarded as a lingua franca, and due to its role within academia internationally, the need to develop communicative competences is now more of a necessity than ever before. Within regions of the world where English holds no official status, it is still gaining ground due to the perceived role in developing and sustaining international commerce and trade. English language teachers have found themselves walking along a discursive fault line (Menard-Warwick, 2014) where learners must be able to demonstrate their linguistic and communicative competences in spoken and written discourse. Bearing in mind that learning a foreign language is a social activity, a genre-based approach (GBA) signifies a "compelling opportunity to help foreign language students to write different texts based on the analysis and evaluation of model genres and the joint construction of them" (Gómez-Burgos, 2017, p. 156).

The pertinence of writing is undeniable not only in academic contexts but also in different disciplines (Hirvela, 2017; Lee \& Deakin, 2016) where this practice is an essential means of communication in situated contexts (Hyland, 2004, as cited in Chala-Bejarano \& Chapetón, 2013); however, for teachers and students alike, the writing process poses a distinct set of challenges within the four walls of the English language teaching classroom. Many cognitive models might ignore that writing is a social activity, lacking exposure to the genres and real contexts (Gómez-Burgos, 2017). "People cannot achieve a communicative purpose if words are not addressing specific cultural or contextual issues" (García Montes et al., 2014, p. 105). Thus, the genre pedagogy was designed as a project to enable students to succeed in their writing in a stage-oriented social process (Rose \& Martin, 2012). Consequently, the present study provides an overview of Systemic Functional Linguistics, emphasizing the Genre-Based Approach to teaching writing in an English as a foreign language ( $\mathrm{EFL}$ ) context, then, it concentrates on the genre of a review text and provides a sample of a pedagogical intervention in the field and its corresponding analysis, guided by the overreaching research question: What is the effect of a GBA, combined with process-based writing and peer feedback, on the production of review compositions and on participants' awareness of the target genre in an EFL course for undergraduate students? To answer the question, the researcher focused on two main objectives: (a) to assess the achievement of the task demonstrated in a final review text written individually, and (b) to find out participants' insights about the pedagogical intervention and their awareness of the target genre. To answer the posed research questions, this study followed the cycle of action research, where the researcher identified that learners needed to succeed in their writing process in a foreign language with a minimum dependence from teachers.

Thus, this article describes the implementation of a GBA combined with process-based writing and peer feedback as an attempt to solve the issue. The paper then analyzes the effects of the implementation to evaluate the suggested solution with the further purpose of making informed decisions related to the practices within the EFL program where this research took place. The study might also provide teaching horizons to the field of EFL and academic writing in foreign languages by describing and evaluating a pedagogical implementation of a GBA in an undergraduate context in Colombia, where there is not only a focus on enhancing academic writing in a general English course but also a purpose of boosting learners' autonomy.

\section{Theoretical Framework}

In this section, the main theories underpinning the study will be explored.

\section{Systemic Functional Linguistics}

Systemic functional linguistics (SFL) puts an emphasis on semogenesis ("meaning making"), that is, understanding texts as intentional acts of meaning and function (Halliday \& Webster, 2009). 
Also, in SFL "language is seen as a social resource; meanings are negotiated in social contexts by social beings" (Burns \& Knox, 2005, p. 235). Thus, in an English as a Foreign Language class, SFL is essentially the glue that solidifies language, meaning and context together (Halliday \& Hasan, 1989). SLF arguably holds the most comprehensive range of applications to support English language learners and their use of words to create meaning (Halliday, 1993). Moreover, SFL has situated itself to be a notable tool for analyzing and teaching academic written discourse by creating a pathway for English learners to increase their meta-linguistic knowledge by removing the focus from grammatical forms and rules to highlighting the importance of using words to make meaning (Halliday, 1978).

For Halliday (1978), language serves three general functions in communication: (1) to express and represent our experience in the world (ideational metafunction), (2) to create relations between producers and receivers of messages (interpersonal metafunction), and (3) to organize texts to form coherent wholes (textual metafunction). Similarly, Halliday and Hasan (1989) explain that experiential meaning has to do with the way words are correlated with events in the world. Interpersonal interaction is similar to social interaction among people. Finally, textual meaning deals with language preferences that lead us to determine the type of genre found in texts. Hence, "it is necessary to teach students that each situation requires different language choices" (García Montes et al., 2014). Therefore, it is recommended to consider the terms of field (the subject matter of discussion at any situation), tenor (statuses and roles of participants) and mode (channel of communication, the symbolic organization of the text; Halliday \& Hasan, 1989; Martin, 1984) for a contextualization of the language.

\section{Genre-Based Approach}

The genre-based approach (GBA) emerged within the field of language teaching to support students as they developed their abilities to produce the written discourse that placed an emphasis on functional language (Rose \& Martin, 2012) occurring within a particular socio-cultural context (Halliday, 1993). By placing an emphasis on functional language, the language used is "a recurrent configuration of meanings" that can drive not only how language is used, but to mobilize the usage of language to help learners develop their voice in an additional language (Martin, 2009, p. 13).

A genre can be understood as a "staged goal-oriented social process;" it can be used as a tool to increase students' literacy and abilities to engage and interact in an additional language given the view of language to create meaning in a social context (Rose \& Martin, 2012). GBA, as Hyland (2007) has described, upholds five key traits that provide a foundation for language learning. The first of these aspects is that pedagogy must be transparent and visible so that learners can identify what they need to learn and understand how this will be reflected in their assessment (Martin, 1999). Secondly, GBA aligns itself with SFL to create a balance between linguistic knowledge, usage, and the given context. Thirdly, GBA is deeply rooted in the notion that teaching ought to be intertwined with support and assistance so that language learners participate in making meaning through the interaction of a shared experience (Martin, 1999), thus the new learning experience is built from previous knowledge. The fourth trait that Hyland identified is that teaching can also be understood as a form of intervention that empowers the learners by creating pathways to assessing, understanding, evaluating, and challenging texts. The fifth and potentially most striking of these five features of GBA is that it aims to increase both the learner's and the teacher's awareness of how texts (genres) function. Hence, both the learner and the teacher are engaged in not only making meaning but analyzing the very root of this meaning though the explicit knowledge presented in each task and analysis of the writing process.

\section{The Teaching-Learning Cycle}

The Teaching-and-Learning Cycle (TLC), proposed in the GBA, offers a platform to help both students and teachers to create meaning within 
the written text. It is a text-based instructional sequence that breaks genre learning into phases to ensure that learning is both explicit and intentional (Rose \& Martin, 2012). The four main stages that provide this balance between genre and making meaning are negotiating the field, deconstruction, joint construction and independent construction.

- Negotiating the Field: In this stage the purpose is to "emphasize the importance of shared experience” (Rose \& Martin, 2012, p. 65). The teacher introduces what the field is and how it will be explored, organized, and recorded. In addition, the teacher explores students' prior knowledge (Rose \& Martin, 2012).

- Deconstruction: The teacher introduces the genre and then reconstructs the message, confirming understanding through interaction with students (Martin \& Rose, 2003, 2007; Rose \& Martin, 2012). In this stage, the class shares experiences, looks critically into models, identifies metalanguage, identifies patterns, and consolidates guidelines about how to write the chosen genre through dialogic interaction (Rose \& Martin, 2012).

- Joint Construction: In this stage, students work in groups or on their own with the teacher's guidance. The teacher's role is of a guide who leads learners carefully through a first experience of construction by building knowledge and writing together to familiarize them with the ideas collected from students themselves for later constituting the features of the corresponding genre (Rose \& Martin, 2012). Students "practice using the structure of the model to scaffold a new text and to discuss as many relevant language features as possible" (Rose \& Martin, 2012, p. 210).

- Independent Construction: In this final stage, individual writing of texts in the same genre takes place (Rose \& Martin, 2012).

\section{The Review Text as a Genre}

Genres are based on the recurrent configuration of meaning in a given text (Rose \& Martin, 2012). According to Martin et al. (1987), genres are "social processes because members of a culture interact with each other to achieve them; goal-oriented because they have evolved to get things done; and staged because it usually takes more than one step for participants to achieve their goals" (p. 59).

The genre tackled in this study is the review text. A review is "an evaluation of a publication, product, service, or company” (Uswar \& Andriani, 2019). Likewise, Gerot and Wignell (1995) define a review as "a text that serves to weigh, assess, and submit a criticism of the work or events". For Rose and Martin (2012), reviews "describe the text and make a judgment about it” (p. 129). Considering the mapping of the genres for schooling proposed by Rose and Martin (2012), reviews imply the evaluation of a text and belong to the classification of text responses (critiquing and evaluating). The authors (2012, p. 130) suggest three stages for writing reviews: context, description of the text, and judgment.

In this study, the object of the review was a "technological text": A mobile application or a webpage. Rose and Martin (2012) state that a text can be verbal, visual, musical, among other types, while text personal responses express feelings and opinions about that text, as performed in the case of reviews. Shared experiences are central in the GBA, since "genres are always about something; if this knowledge is not shared, it is very difficult for students to concentrate on the structure of the new language they are being scaffolded to learn" (Rose \& Martin, 2012, p. 84).

\section{Process-Based Writing Curriculum}

In process-based writing, instead of producing various finished-products that end up as several grades, students produce more than a single product that constitute one final grade. Each of those 
single products is exposed to feedback and formative evaluation since the emphasis is on supporting students through stages of writing such as pre-writing, drafting, revising, etc. (Cushing Weigle, 2014). In Process-based writing, the instruction is learnercentered while students undertake a big portion of the writing process, by analyzing what they write, how they write it, and the evaluation of their own writing (Butler-Pascoe \& Wiburg, 2003).

Rothery's initial curriculum genre for teaching writing, called a language-based approach, borrowed some stages of process-based writing curriculum: drafting, conferencing, and publishing (as cited in Rose \& Martin, 2012). Thus, aligned with process-writing advocates, but with noteworthy innovations, Rothery's proposal was the following:

1. Introducing a genre

2. Focusing on a genre

3. Jointly negotiating the genre

122

4. Researching

5. Drafting

6. Conferencing

7. Publishing

\section{Peer Feedback}

Peer feedback is defined as an action where "students learn to describe the organizational structure of a peer's paper, paraphrase it, and [suggest] what the author might do to improve the work" In this process, the text is "a social construction" (Bruffee, 1984, as cited in Breuch, 2004). Peer correction might be conceived as an effective strategy when writing due to the learners' active role in their own process (Ramírez Balderas \& Guillén Cuamatzi, 2018). Thus, peer feedback boosts autonomy, cooperation, interaction, involvement, and student-centered learning (Hirvela, 1999; Sultana, 2009).

In peer feedback the learner plays a double role: as a reader, the student faces the challenge of reading critically, interpreting the message and identifying areas of improvement; as a writer, the student needs to be open to suggestions in order to be self-reflective and think critically when revising their own work (Moussaoui, 2012). For students to carry out the peer feedback technique proposed in this study, teachers provided them with feedback models, guiding questions, assessment checklists, and error correction symbols. Correction symbols allow learners to revise their understanding of certain linguistic items, form and function of a variety of lexical and grammatical elements (Ramírez Balderas \& Guillén Cuamatzi, 2018). Moreover, the teachers have the responsibility to model the academic discourse students need to focus on during peer feedback (Bruffee, 1984, as cited in Breuch, 2004).

\section{Instruction on Writing in a Foreign Language}

Different approaches to improving writing have been researched aboundingly, however, each of the studies focuses on different issues, as will be exposed in this section through some samples of the research in the field. Dealing with the review text, Uswar and Andriani (2019) explored the abilities of university students to write a review about a novel. Findings reported that students' pieces of writing were generally good, but with linguistic errors. However, the study did not consider either SFL or GBA in their implementation. Concerning SFL and GBA, Gómez-Burgos (2017) conducted an action research study in a public university in Chile which aimed to implement a genre-based approach to writing expository essays. After comparing pre- and post- intervention papers, the author assures that the implementation was successful. It must be highlighted that the researched population belonged to a pedagogy program, that is to say, pre-service teachers who are generally well-prepared in academic writing.

In the same vein, in Japan, Nagao (2019) implemented a genre-based approach to text-based writing lessons to explore EFL learners' psychological attributes and awareness of a discussion genre essay. Findings suggested some improvements in the lexicogrammatical features and 
generic structures of the genre. The implementation also included an analysis of peers' essays, but with research purposes only. A sample in a foreign language different from English is Troyan's (2016) research. The author reported a case study about the implementation of a GBA when teaching Spanish as a foreign language. The researcher analyzed a pre and posttest of a student in a task related to tourist landmark descriptions. Findings suggested that teaching explicitly in a particular academic genre enhanced the development of more detailed, informative, and cohesive writing.

About assessment in GBA, Pessoa et al. (2017) followed the principles of SFL and adapted the $3 \times 3$ professional learning toolkit suggested by Humphrey et al. (2010, as cited in Pessoa et al., 2017) to examine emergent arguments in a firstyear university history class. $3 \times 3$ is a professional learning "toolkit" that "describes key linguistic features of disciplinary academic genres by focusing on the ideational, interpersonal, and textual meanings of language, and taking into consideration how these meanings are realized linguistically at the whole text, paragraph, and sentence and clause levels" (Pessoa et al., 2017, p. 46). The authors discussed how a language-focused conceptualization of argumentative writing can be beneficial for second language writing and other disciplines dealing with the issue of academic writing. The rubric applied in this study will be further explained in the section dealing with the pedagogical implementation (See appendix A).

\section{Method}

In this section, the research design, research method, and the procedures followed to collect and manage data will be explained.

\section{Context and Participants}

This study was conducted in a private university in Bogotá, Colombia, where all students take seven levels of English as a Foreign Language (EFL) as a graduation requirement. This context has implemented a solid writing approach for over 5 years, focusing on a specific genre in each of the levels taught and combining it with a process-based approach. The participants were 54 learners from different academic fields, who were enrolled in a pre-intermediate (A2.2 CEFR) EFL course from the university.

In foreign language instruction, a great deal of attention, time, and resources are devoted to the teaching of academic writing (Hinkel, 2014), especially in higher education where learners are expected to acquire skills that will allow them to negotiate meaning in the written form in the workplace or during graduate education. Furthermore, globalization and technology have made written communication essential in business, education, social networking, etc. (Cushing Weigle, 2014). Thus, this study was implemented in an English as a Foreign Language (EFL) program where writing, being a productive skill, has had a prominent role. For over 5 years, each of the course levels of the program has focused on writing a specific genre, emphasizing the norms of a specific kind of writing (Harmer, 2001). The program followed a process-based approach: outlines, drafts, and final versions to guide learners through a scaffolded process of writing compositions with a clear rhetorical structure and a social and communicative function, while also taking formative assessment into consideration.

In that context, a teachers' survey is applied at the end of every academic semester for the curriculum sub-committee to analyze the strengths and opportunities to improve the processes carried out within the EFL program. For analyzing the writing process, a needs analysis survey was applied to 26 teachers. Although the writing process had been academically successful, in terms of well-written products, the program staff reported that students needed to take more responsibility in their own learning process. Besides, grading drafts and various versions of the text was draining. Therefore, findings implied the need to diminish the teacher-grading load and to give students' participation more prominence in the learning process. For students' engagement, 
Table 1 Data collection instruments and implementation stages

\begin{tabular}{|c|c|c|}
\hline Instrument & Purpose & Stage \\
\hline $\begin{array}{l}\text { Online survey } \\
\text { (See appendix B) }\end{array}$ & $\begin{array}{l}\text { - To find out participants' insights about the } \\
\text { implementation. }\end{array}$ & At the end of the joint construction stage \\
\hline $\begin{array}{l}\text { Students' artifacts: a review } \\
\text { text (See appendix C) }\end{array}$ & $\begin{array}{l}\text { - To measure and assess the achievements of the learning } \\
\text { goals proposed for this GBA implementation. }\end{array}$ & $\begin{array}{l}\text { A Review text: after the independent } \\
\text { construction stage }\end{array}$ \\
\hline Online game: Kahoot & & Kahoot: during the joint construction stage \\
\hline Focus Group & - To find out participants' insights about the implementation. & \\
\hline (See appendix D) & $\begin{array}{l}\text { - To triangulate and validate the responses from the online } \\
\text { survey. }\end{array}$ & After the independent construction stage \\
\hline
\end{tabular}

it is increasingly important that they take a more active role in the learning and assessment processes (Katz, 2014). Thus, the sub-committee came up with an adaptation of the teaching and learning cycle of a GBA previously implemented (1) to place more prominence on the students' active participation in the joint construction phase by including systematic peer feedback and (2) to preserve the well-written products by keeping some steps of process-based writing.

\section{Research Design}

This study followed the action research cycle. Action research targets to describe and analyze a systematic implementation to solve a problem in the educational field (Edwards \& Willis, 2014; McKernan \& McKernan, 2013). Therefore, action research is related to the ideas of "reflective practice" and "the teacher as a researcher" (Burns, 2010). The teacherresearcher implements the plan, reflects on it, and makes any changes, if necessary (Handscomb \& MacBeath, 2009). Ellis (2013) defines the different stages of the action research cycle as follows:

1. Identifying an issue or problem relevant to a specific instructional context.

2. Obtaining information relevant to the problem issue.

3. Working out a possible solution to this problem and devising ways of trying this out.

4. Trying out the solution in the specific instructional context.
5. Collecting data to investigate whether the solution is effective.

Stages 1 and 2 have already been addressed in this paper; the implementation of the possible solution will be further described as the pedagogical intervention.

\section{Data collection}

The instruments were applied as described in Table 1.

All instruments were validated and piloted before the implementation. They were revised along with an external researcher and applied to a group of students who did not take part of the study with the purpose of assuring that the questions and procedures were clear for the participants.

\section{Data Analysis}

This action research applied a mixed-methods approach to data analysis in which "the investigator collects and analyses data, integrates the findings, and draws inferences using both qualitative and quantitative approaches or methods in a single study" (Tashakkori \& Creswell, 2007, p. 4). A mixed-methods approach allows the answering of research questions as well as the corroboration of findings by contrasting data from qualitative and quantitative nature (DeCuir-Gunby, 2008). In this study, qualitative data were analyzed following Grounded Theory (Corbin \& Strauss, 2015). 
and quantitative data were analyzed by carrying out a descriptive statistic summary (Research Connections, 2019; Sharma, 2019).

Data were stored in an Excel file; participants were given a number to protect their identity and to avoid research bias in the analysis. Data were analyzed under the light of the research question and objectives, focusing on (1) the achievement of the task and (2) participants' insights about the pedagogical intervention.

\section{Pedagogical Intervention}

In action research, the teacher-researchers implement a pedagogical intervention to solve a problem in an educational context (Edwards \& Willis, 2014; McKernan \& McKernan, 2013). In this study, a GBA was implemented as an attempt to give students more responsibility in their own learning process by following an autonomous writing cycle, with the teacher acting only as a guide. Participants were expected to be able to achieve the learning goals posed for the writing skill, demonstrating mastery of the genre by producing a review about a new topic independently. The target task dealt with reviews of Mobile Apps or Webpages. Since reviews are a common practice in the modern world in social situations such as evaluating a book, a movie, a TV series, etc. and participants are very well-acquainted with the webpages and apps, experiential sharing was expected to be facilitated.

The three stages of the teaching and learning cycle of the GBA were implemented during a 16-week semester, focusing on writing a three-paragraph review. When perusing the social purpose of a review to evaluate a text, Rose and Martin (2012, p. 130) suggested the following stages: context, description of the text, and judgment, which were enclosed in each of the requested paragraphs. The authors also emphasize the Key Language needed to negotiate meaning according to the genre. Consequently, the target task was designed as described in Table 2.

In the same vein, the task included a rhetorical structure for written academic discourse, which is fundamental in second language (L2) instruction considering that the socio-cultural traditions in written discourse may vary from L1 to L2 (Hinkel, 2014). Hence, along the course, participants co-constructed paragraphs with topic sentences, supporting details and restatements to build a review composition. At the end of the semester, participants needed to demonstrate the mastery of the genre by writing a three-paragraph review of a different app/webpage individually.

The final written product was evaluated using an analytical rubric that had been designed by the

Table 2 Task Description

\begin{tabular}{|c|c|c|c|}
\hline Genre & Social Purpose & Stages & Key Language \\
\hline A review text & $\begin{array}{l}\text { Responding to a text: } \\
\text { Critiquing and Evaluating }\end{array}$ & $\begin{array}{l}\text { Paragraph 1: Definition of the app/ } \\
\text { Webpage (Context and description) } \\
\text { Paragraph 2: Positive features } \\
\text { (judgment) }\end{array}$ & $\begin{array}{l}\text { One of the best/most famous, most recognized is... } \\
\text { It is defined as... It contains... It has ... } \\
\text { It is a...fantastic, perfect, famous, exciting, } \\
\text { It is the best...., the most important... . A positive } \\
\text { feature is... } \\
\text { It also has... issues, problems, } \\
\text { concerns, } \\
\text { disadvantages, } \\
\text { The drawbacks of..., The negative point is... A } \\
\text { negative consequence is... . A downside of... is... }\end{array}$ \\
\hline
\end{tabular}

Number of words: $280-300$ 
EFL program curriculum subcommittee to assess the writing products of the different English levels that the university offers (see appendix A). Teachers had to use the overall rubric and adapt it to each of the tasks and competencies of the course. Then, the general criteria of the institutional rubric were implemented, permitting the inclusion of some descriptors related to only a part of the $3 \times 3$ matrix suggested by Humphrey et al. (2010). The $3 \times 3$ framework analyzes the ideational, interpersonal, and textual meanings of language in the levels of whole text, paragraph, and sentence and clause (Pessoa et al., 2017). However, the present study focused on the analysis of the "whole text" only, which Humphrey et al. (2010) also called "Genre and Register." This $3 \times 3$ matrix also considers the concepts of field, tenor, and mode (Halliday \& Hasan, 1989; Martin, 1984) applied in the assessment of this intervention in the following way:

1. Ideational Meaning: Resources for specialized construction and formal knowledge of discipline area, also referred to as Field (Humphrey et al., 2010). Incorporated in the institutional rubric in the following criteria:

a) Writing is profound and detailed showing a deep understanding of the topic.

b) The composition reflects knowledge and critical thinking about the topic (See appendix A).

2. Interpersonal Meaning: Resources for convincing the reader in critical yet authoritative ways, also known as tenor (Humphrey et al., 2010).
Reflected in the following criterion: a) Tone and word choice are appropriate for the audience (See appendix A).

3. Textual Meaning: Resources for organizing clearly scaffolded abstract texts, or related to mode (Humphrey et al., 2010). Incorporated in following the criteria:

a) Follows the rhetorical structure for a Review.

b) Stays on topic throughout the entire piece.

c) The topic sentences and supporting ideas are clear and connected to maintain the focus (See appendix A).

All in all, the teaching and learning cycle implemented is summarized in Table 3.

\section{Results}

In this section the data analysis and the implications of study will be explained, taking the achievement of the task and the participants' insights into consideration.

\section{Task Achievement}

Using the rubric in Appendix A, the teacher graded 53 review texts which were written by the participants in the independent construction stage. Performance assessments consisted of two components: (1) a prompt that sets the task for the assignment and (2) a way of scoring the language that students produce, as Katz (2014) proposed. The prompt consisted of writing a three-paragraph review about 1 of the 4 options provided.

Table 3 Teaching and Learning Cycle Implemented

\begin{tabular}{llc}
\hline \multicolumn{1}{c}{ Stage } & \multicolumn{1}{c}{ Activities } & Time \\
\hline Negotiating the field & - The teacher presented the main tasks and the implementation planned for the semester. & Week 1 \\
& - The teacher and students explored prior knowledge from web pages, apps, and the social \\
& context of reviews. & \\
Deconstruction & - Through dialogic interaction, the teacher guided the discovery of the function, the rhetorical & Weeks \\
- Learning about the & structure, and key language that students deconstructed from provided models. & $1-5$ \\
language, purpose, and & - The teacher devoted a l-hour-session weekly to the modeling and analysis of topic & \\
structure of the text. & sentences, supporting details, and restatements for each of the paragraphs. & \\
& - Students deconstructed a review text into an outline. &
\end{tabular}


Table 3 Teaching and Learning Cycle Implemented (cont.)

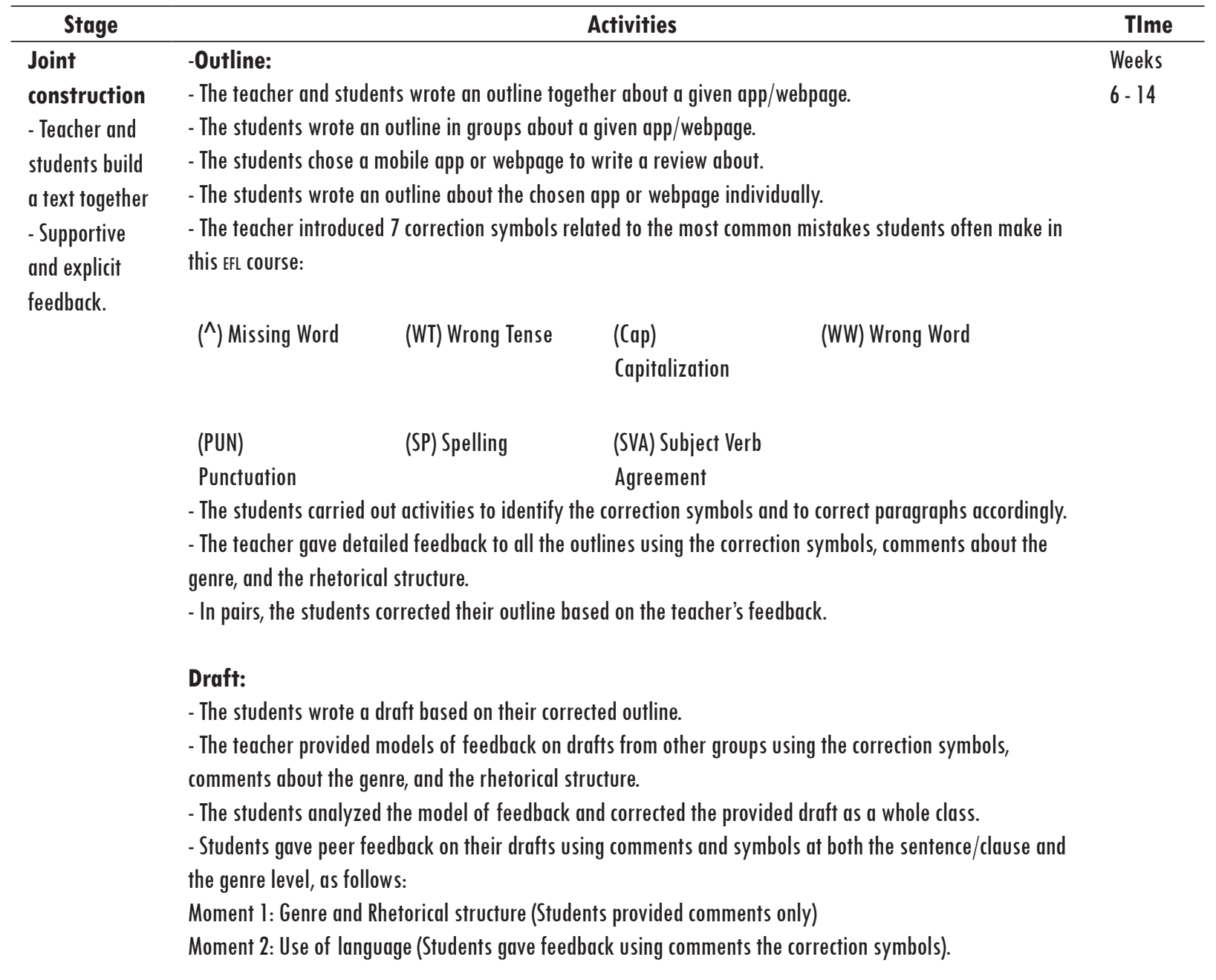

Independent - The teacher introduced the rubric that was going to be used to assess the independent construction of the 
The score was guided by the rubric which included criteria for task achievement, focus, text relevance, and general linguistic usage on a grading scale from 0 to 5.0.

To analyze the overall results obtained from grading students' samples, keeping all the criteria in the rubric in mind, the researcher used descriptive statistics to carry out a measure of central tendency, aiming to describe the behavior of the set of data collected and to break it into the simplest form (Research Connections, 2019; Sharma, 2019). As a result, the Mean (the sum of a variable's values divided by the total number of values), the Median (the middle value of a variable), and the Mode (the value that occurs most often) were calculated as shown in Table 4.

The mean (4.27) denotes a favorable production of the written task, being 1.27 points above the passing grade (3.0). Similarly, the median and the mode were both calculated in 4.25. The lowest result was obtained by participant 2 , with a 3.0 grade; hence, no participant failed the task. On the other hand, participants 7 and 27 had an outstanding performance, obtaining the highest grade (5.0). Two samples of students' writings are provided in appendix $\mathrm{C}$.

In a similar vein, the average score in the criterion "Task Achievement" was 1.33 out of a maximum of 1.5. Similarly, the mode was the maximum score (1.5), which was obtained by 28 students, and the median also corresponded to the maximum score (1.5). These findings seem to indicate that most students achieved the social purpose of the

Table 4 Central Tendency of Participants' Grades

\begin{tabular}{lll}
\hline \multicolumn{1}{c}{ Measure } & Result & Details for calculation \\
\hline Mean & 4.27 & Average grade \\
Median & 4.25 & $\begin{array}{l}\text { Lowest grade: } 3.0 \\
\text { Highest grade: } 5.0\end{array}$ \\
Mode & 4.25 & Frequency: 13 times \\
\hline
\end{tabular}

53 artifacts analyzed genre and followed the rhetorical structure when working on their own in the independent construction stage. The central tendency regarding the achievement of the task is displayed in Table 5.

Equally, the results from the online game (Kahoot) suggest an understanding of the genre and identification of the most suitable features for writing a review, with an $88 \%$ mean score in the game. In the initial stages of the implementation, students demonstrated a lack of prior knowledge related to the identification of the genre used in such contexts. As Hinkel (2014) states, many features of academic writing that might represent conventionalized characteristics of a genre are explicitly and persistently taught in ESL/ EFL since they are not always found in written discourse traditions other than the Anglo-American one. Thus, in the online survey, the researcher also inquired about learners' previous experience with the review text. Results showed that only $40 \%$ of participants had previous experience writing reviews in Spanish and $26 \%$ in English.

\section{Participants' Insights}

Students' insights about the intervention, their learning process and performance were explored through a focus group and an online survey that contained a Likert scale and 4 open-ended questions. In the Likert scale, participants showed confidence in their writing skills, as shown in Figures 1 and 2, where students showed their agreement with the statements (1) over the semester, my overall writing skills have improved and (2) I understood the different sections of the review composition.

Table 5 Central Tendency of Task Achievement

\begin{tabular}{lcl}
\hline \multicolumn{1}{c}{ Measure } & Result & Details for calculation \\
\hline Mean & 1,33 & Average score \\
Median & 1,5 & $\begin{array}{l}\text { Lowest score: } 0,75 \\
\text { Highest score: } 1,5\end{array}$ \\
Mode & 1,5 & Frequency: 28 times \\
\hline
\end{tabular}

53 artifacts analyzed 


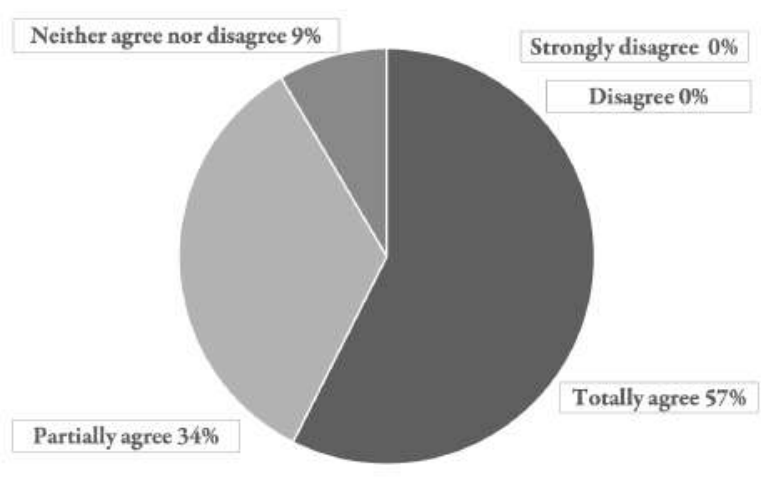

Figure 1 Responses to the Likert scale, statement 1

For the open-ended questions and focus groups, responses were tabulated and coded following the Grounded Theory (Corbin \& Strauss, 2015). Table 6 shows findings concerning the two emerging categories: effective practices and gains in the learning process.

These findings suggest that participants perceived that a genre-based approach and the stages of the

Table 6 Emerging Codes, Subcategories, and Categories

\begin{tabular}{|c|c|c|}
\hline Codes & Subcategories & Category \\
\hline Scaffolded process & GBA and TIC & $\begin{array}{l}\text { Effective } \\
\text { practices }\end{array}$ \\
\hline \multicolumn{3}{|l|}{ Deconstructing the text } \\
\hline \multicolumn{3}{|l|}{ Constructing the text with the } \\
\hline \multicolumn{3}{|l|}{ teacher and peers } \\
\hline \multicolumn{3}{|l|}{ Key language provided } \\
\hline \multicolumn{3}{|l|}{ Learning about the genre } \\
\hline \multicolumn{3}{|l|}{ Scaffolded process } \\
\hline Writing outlines & Process-based & \\
\hline \multicolumn{3}{|l|}{ Writing drafts } \\
\hline \multicolumn{3}{|l|}{ Peer feedback } \\
\hline & Feedback & \\
\hline Error correction procedures & procedures & \\
\hline \multicolumn{3}{|l|}{ Self-reflection } \\
\hline Understanding mistakes & Metacognition & $\begin{array}{l}\text { Gains in the } \\
\text { learning process }\end{array}$ \\
\hline Awareness of the process & & \\
\hline
\end{tabular}

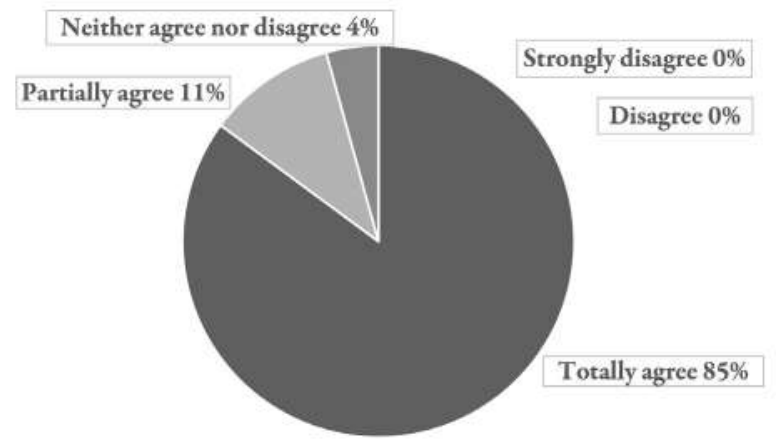

Figure 2 Responses to the Likert scale, statement 2

teaching and learning cycle were practices that contributed to the improvement of their writing skills, as exemplified in Excerpts 1 and 2 below:

I am better at writing thanks to the activities and the structure of, in this case, a review, its function and everything that goes in each paragraph. It seems to me that it is very good that they give all the parameters to carry out the activity (Excerpt 1, participant 18, online survey).

The activities of evaluating the webpage, using positive or negative expressions or connectors and thus identifying each part of a review helped me to write better (Excerpt 2, participant 41, online survey).

Likewise, participants valued components of process-based writing, such as writing outlines and drafts: For instance, the following excerpt refers to a process-based approach:

It helped me to do the review by writing part by part and making several versions, as outlines and drafts (Excerpt 3, participant 20, online survey).

In addition, participants also attributed their success to the feedback procedures implemented. They valued being involved in their own learning process, as illustrated in the following excerpts:

[...] when you write, you think that the idea, as it is, and as you wrote it, is fine. But when another person reads it, they may not understand, then they make you realize what errors you have and how you can improve them (Excerpt 4, participant 29, online survey).

I found it interesting when we had to evaluate other classmates; since normally it is the teacher the one 
who evaluates and gives opinions, but in this case, it is... like... between us, that was interesting (Excerpt 5 , participant 23, focus group).

Participants also expressed other gains in the learning process apart from the achievement of the task. They showed awareness of the process, self-reflection, and metacognition as expressed in Excerpts 6 and 7:

All the writing exercises made me improve and analyze the reviews because I believe I had never thought about how to improve my writing (Excerpt 6, participant 15 , online survey).

When writing, the process is important: first, have a topic and examples of the kind of text. Then, do it step by step. Learn first, what the text is, what it is made of, each of the parts, the vocabulary you need for that text, the steps. When we already understand that, then, there you go, what has to go in the first, in the second, and in the third paragraph, we put it into words, phrases and then put everything together in a complete composition (Excerpt 7, participant 14, focus group).

On the other hand, although peer feedback was perceived as an effective practice, opinions were divided as noted in Figure 3, where students showed their agreement to the statement (3) my classmate's feedback was crucial to my success.

Figure 3 shows a clear division in students' perceptions about peer feedback. It could be said that $55 \%$ of the participants believed the strategy was useful, while $15 \%$ disagreed and $30 \%$ had a neutral opinion. Similarly, in the focus group and the open-ended questions from the online survey, participants pointed out that providing and receiving feedback was the biggest challenge in the implementation, as summarized in Excerpt 9:

The text feedbacks should be done by the teacher in all cases to have accurate corrections (Excerpt 8, participant 24, online survey).

Likewise, Excerpt 9 below denotes a challenge for the student due to the responsibility that the process entitles, but she still recognizes that the procedure was helpful:

For me, the biggest challenge was actually correcting my classmates' text, as collaborative work is obviously

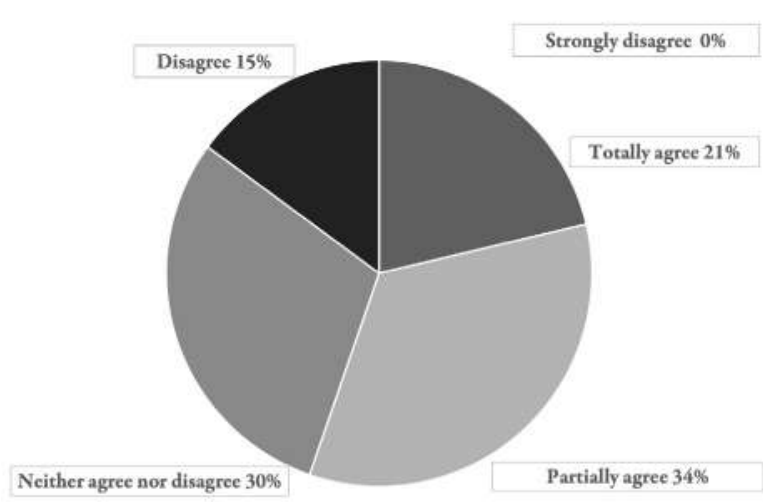

Figure 3 Responses to the Likert scale, statement 3

very important, but for me it was correcting because I had to do it very conscientiously because there are things that I didn't know at that time, and then if I am correcting I can't tell her something wrong, right? So, I think it was a challenge for me to correct the other person, but it was also very important for me what the other person told me about my work. If I didn't know how to write something, then I would go to the dictionary and look it up, look at how to build sentences, check my notes to know if the paragraph was complete. It took a long time reviewing it, but I think we both did it well (Excerpt 9, participant 31, focus group).

To sum up, findings suggest an outstanding achievement of the task. In the same vein, learners demonstrated a broad understanding of the genre, its social purpose, and the most suitable features for writing a review. Also, the study seemed to have generated a positive impact on the participants' insights since they showed confidence in their writing skills after the implementation, leading also to self-reflection and metacognitive behaviors. Moreover, participants perceived that a genre-based approach, the activities of the teaching and learning cycle, and the components and process-based writing were practices that contributed to the improvement of their writing skills. On the other hand, a clear division in students' perceptions of peer feedback was found, as participants believed it was a beneficial but challenging practice.

\section{Discussion}

In this study, the implementation of a genre-based approach (GBA), combined with components of 
process-based writing and peer feedback, was analyzed to measure its impact on the achievement of the task when writing reviews as well as its impact on participants' perceptions. The researcher aimed to encourage students' participation and autonomy in the writing process, with a minimum amount of direct teacher intervention, without affecting the quality of the written products. Findings indicate that the intervention provided some benefits in the learning process, such as a remarkable achievement of the task and some metacognitive behaviors. Furthermore, participants valued the GBA implemented, process-based writing and feedback procedures as practices that helped them to achieve the task successfully.

These findings align with Gómez-Burgos' (2007) study. The author states that a GBA is efficient in foreign language instruction since students' artifacts improve substantially after the implementation. As in the case of this study, Gómez-Burgos (2007) found positive results on the participants' pieces of work when implemented a GBA to write expository essays. It is worth clarifying that, in Gómez-Burgos' research, in the 2007 study, the participants were pre-service teachers who are expected to have more experience with academic writing than the population from the target study. Similarly, Nagao (2019) found a positive impact when implementing a GBA focused on a discussion genre, with improvements on language and awareness of the genre. Nagao's implementation aligns with the present study in terms of the approaches implemented: GBA and peer feedback; however, in that study, participants evaluated their peers to evaluate them and to generate data from the process. The present research not only aimed to teach a genre explicitly to achieve coherent and cohesive writing products, but it also exposed learners to a didactic cycle where the feedback of their peers had a prominent role, as teachers aimed for learners to gain autonomy.

The inclusion of peer feedback in the learning process has been previously discussed by scholars
(Bruffee, 1984, as cited in Breuch, 2004; Nagao, 2019; Susanti \& Indawan, 2020; Durán-Bautista \& Huertas-Malagón, in press) and in the present study, it was incorporated in a GBA. In a GBA learners are expected to interact with an expert around a shared experience and the TLC paves their path to an independent construction of knowledge. This proposal of fusing the two approaches provides the opportunity to reflect upon the principles of autonomy, where the teacher is no longer the main actor who owns knowledge in a learning environment. According to Higgs (1987), teachers need to involve students to operate the learning process jointly and to help them learn from their past experiences. Gardner and Miller (1999) suggest that in autonomous learning the teacher takes the roles of counselor, facilitator, material developer, manager, among others. Within their tasks, teachers present materials, model, elicit information, give suggestions, suggest self-assessment techniques, give feedback on self-assessment, etc. (Riley, 1997).

Although participants recognized peer feedback as an effective strategy, it was also perceived as a challenge since learners might feel insecure when advising others or would not trust their classmates' recommendations. These findings support other studies where learners of foreign languages preferred teacher feedback for accuracy and trust, but they could still recognize advantages of the practice for their learning process (Durán-Bautista $\&$ Huertas-Malagón, in press; Susanti \& Indawan, 2020). In addition, Jones (2019) claims that the transition from dependent learning to selfdirected learning takes time. These conclusions might suggest that students need more exposure to gain confidence and to switch the learning culture for autonomous learning to prevail. For instance, in the present study, participants were guided to provide feedback to their peers based on models, guided questions, checklists, and correction symbols; and the fact that some learners were not confident about their knowledge to provide accurate peer feedback forced them to find 
alternatives for reviewing and learning on their own. Furthermore, peer feedback can be an alternative technique in large classrooms where the teacher is unable to attend to every individual student (Renaud et al. 2007; Susanti \& Indawan, 2020), as in the case of this study.

In relation to the assessment of the written compositions, the present research implemented a rubric as Pessoa et al. (2017) did. Nevertheless, the rubric was not identical to the $3 \times 3$ learning toolkit proposed by Humphrey et al. (2010, as cited in Pessoa et al., 2017) since the target course belonged to a program which had designed an institutional analytical rubric according to the curricular needs of all of the EFL levels that the university offers. Thus, the curriculum sub-committee adapted the existing rubric with descriptors related to ideational, interpersonal and textual meaning in the criteria of "task achievement," "focus," and "Text Relevance” criteria.

Therefore, this action research provided pedagogical significance since participants were guided through a Teaching and Learning Cycle in a collaborative and autonomous environment that provided them with the tools to face the task of writing a review text about an unexpected topic on their own. In the implementation, participants used the language to negotiate meaning and managed to take part in the social context used for writing reviews. Participants evaluated different web pages and apps, providing supporting details for their assertions in a coherent rhetorical structure while remaining aware of the transferability of the acquired skills to other life situations. In that way, it can be stated that learners developed more than a mechanical skill (Chala \& Chapetón, 2013).

This study contributes not only to the field of GBA, but also to the field of EFL instruction and pedagogy. The analysis carried out serves as a reflective evaluation of the pedagogical practices implemented in the target course that will support the teaching staff to make informed instructional decisions in their courses. The detailed implementation described in this paper might provide a model to be applied in other EFL levels in the program itself and in other EFL programs that aim to enhance the writing skill. It was found that learners neither had significant prior-knowledge in the field of academic writing nor in genre identification and production; thus, this paper might also provide a starting point for other subjects in schools or higher education to explore the field, even in students' first language.

\section{Acknowledgments}

The researcher would like to thank Prof. Rosa Dene David for her support in co-designing and validating the data collection instruments that were applied in the present study. The author also thanks the curriculum subcommittee of the EFL program at Universidad de La Sabana for the advances implemented in the program regarding the GBA that was here studied. She would like to especially thank the Level 4 coordinator from the years 2019 and 2020 (Yeimy Suarez) for the design of many of the teaching resources employed in this study. This paper would not have been possible without these professionals' enthusiasm for teaching and learning.

\section{References}

Breuch, L.-A. K. (2004). Virtual peer review: Teaching and learning about writing in online environments. State University of New York Press.

Burns, A. (2010). Doing action research in English language teaching: A guide for practitioners. Routledge. https://doi.org/10.4324/9780203863466

Burns, A., \& Knox, J. (2005). Realisation(s): Systemicfunctional linguistics and the language classroom. In Bartels N. (Ed.), Applied linguistics and language teacher education (pp. 235-259). Springer. https:// doi.org/10.1007/1-4020-2954-3_14

Butler-Pascoe, M. E. \& Wiburg, K. M. (2003). Technology and teaching English language learners. Pearson College Division.

Chala-Bejarano P. A. \& Chapetón, C. M. (2013). The role of genre-based activities in the writing of argumentative essays in EFL. Profile, 15(2), 127-147.

Corbin, J., \& Strauss, A. (2015). Basics of qualitative research: Techniques and procedures for developing grounded theory ( $4^{\text {th }}$ Ed.). Sage Publications. 
Cushing Weigle, S. (2014). Considerations for teaching second language writing. In Teaching English as a second or foreign language. ( $3^{\text {rd }} \mathrm{Ed}$.). National Geographic Learning.

DeCuir-Gunby, J. (2008). Designing mixed methods research in the social sciences: A racial identity scale development example. In J. Osborne (Ed.), Bestpractices in quantitative methods (pp. 125-136). Sage. https://doi.org/10.4135/9781412995627.d11

Durán-Bautista, D. C. \& Huertas-Malagón, S. P. (In press). Mobile phones-assisted practice and note-taking in foreign language oral production. International Journal of Mobile and Blended Learning, 12 (4).

Ellis, R. (2013). Language teaching research and language pedagogy. John Wiley \& Sons Inc. https://doi. org/10.1002/9781118271643

Edwards, C., \& Willis, J. W. (2014). Action research: Models, methods, and examples. Information Age Publishing.

García Montes, P. A., Sagre Barboza, A. M., \& Lacharme Olascoaga, A. I. (2014). Systemic functional linguistics and discourse analysis as alternatives when dealing with texts. PROFILE: Issues in Teachers' Professional Development, 16(2), 101-116. https://doi. org/10.15446/profile.v16n2.38113

Gerot, L., \& Wignell, P. (1995). Making sense of functional grammar: An introductory workbook. Gerd Stabler.

Gómez-Burgos, E. (2017). Use of the genre-based approach to teach expository essays to English pedagogy students. HOW, 24(2), 141-159. https:// doi. org/10.19183/how.24.2.330

Halliday, M. A. (1993). Towards a language-based theory of learning. Linguistics and Education, 5(2), 93-116. https://doi.org/10.1016/0898-5898(93)90026-7

Halliday, M. A. K. (1978). Language as social semiotic. The social interpretation of language and meaning. Edward Arnold.

Halliday, M. A. K., \& Hasan, R. (1989). Language, context and texts: Aspects of language in a social-semiotic perspective. Oxford University Press.

Halliday, M. A. K. \& Webster, J. J. (2009). Continuum companion to systemic functional linguistics. Continuum International Publishing Group.

Hammond, J. \& Derewianka, B. (2001). Genre. In R. Carter \& D. Nunan (Eds.), The Cambridge guide to teaching English to speakers of other languages. Cambridge University Press. https://doi.org/10.1017/ CBO9780511667206.028

Handscomb, G., \& MacBeath, J. (2009). Professional development through teacher enquiry. In A. Lawson
(Ed.), Action research: Making a difference in education (Vol. 1). NFER.

Harmer, J. (2001). The practice of English language teaching. Longman. https://doi. org/10.1177/003368820103200109

Higgs, J. (1987). Programe structure and self-direction in independent study programe. Higher Education Research and Development Society of Australia, 9, 258-261.

Hinkel, E. (2014). Culture and pragmatics. In teaching English as a second or foreign language ( $3^{\text {rd }} \mathrm{Ed}$.). National Geographic Learning.

Hirvela, A. (1999). Collaborative writing instruction and communities of readers and writers. TESOL Journal, 8(2), 7-12.

Hirvela, A. (2017). Argumentation and second language writing: Are we missing the boat? Journal of Second Language Writing, 36, 69-74. https://doi. org/10.1016/j.jslw.2017.05.002

Humphrey, S., Martin, J. R., Dreyfus, S., \& Mahboob, A. (2010). The 3X3: Setting up a linguistic toolkit for teaching academic writing. In A. Mahboob \& N. K. Knight (Eds.), Appliable linguistics (pp. 185-199). Continuum.

Hyland, K. (2007). Genre pedagogy: Language, literacy and L2 writing instruction. Journal of Second Language Writing, 16(3), 148-164. https://doi. org/10.1016/j.jslw.2007.07.005

Jones, D. (2019). Cultivating self-directed learners start here. Flipped Learning Review. Retrieved October 8, 2019, from https://Alr.flglobal.org/ cultivating-self-directed-learners-starts-here/

Katz, A. (2014). Assessment in Second Language Classrooms. In teaching English as a second or foreign language. $\left(3^{\text {rd }}\right.$ Ed.). National Geographic Learning.

Lee, J. J., \& Deakin, L. (2016). Interactions in L1 and SL undergraduate student writing: Interactional metadiscourse in successful and less-sucessful argumentative essays. Journal of Second Language Writing, 33, 2134. https://doi.org/10.1016/j.jslw.2016.06.004

Martin, J. R. (1984). Language, register, and genre. In F. Christie (Ed.), Children writing: Reader (pp. 2130). Deakin University Press.

Martin, J. R. (1999). Factual writing: Exploring and challenging social reality. Deakin University Press.

Martin, J. R. (2009). Genre and language learning: A social semiotic perspective. Linguistics and Education, 20, 10-21.https://doi.org/10.1016/j. linged.2009.01.003 
Martin, J. R., Christie, F., \& Rothery, J. (1987). Social processes in education: A reply to Sawyer and Watson (and others). In I. Reid (Ed.), The place of genre in learning (pp. 58-82). Center for Studies in Literacy Education, Deakin University.

Martin, J. R. \& Rose, D. (2003). Working with discourse: Meaning beyond the clause. Continuum.

Martin, J. R. \& Rose, D. (2007). Interacting with text: the role of dialogue in learning to read and write. Foreign Languages in China 4.5, 66-80.

McKernan, J., \& McKernan, J. (2013). Curriculum action research: $A$ handbook of methods and resources for the reflective practitioner. Routledge. https://doi. org/10.4324/9781315041742

Menard-Warwick, J. (2014). English language teachers on the discursive faultiness: Identities, ideologies and pedagogies. Multilingual Matters. https://doi. org/10.21832/9781783091119

Moussaoui, S. (2012). An investigation of the effects of peer evaluation in enhancing Algerian students' writing autonomy and positive affect. Procedia: Social and Behavioral Sciences, 69, 1775-1784. https://doi. org/10.1016/j.sbspro.2012.12.127

Nagao, A. (2019). The SFL genre-based approach to writing in EFL contexts. Asian-Pacific Journal of Second and Foreign Language Education, 4(1), 6. https://doi. org/10.1186/s40862-019-0069-3

Pessoa, S., Mitchell, T. D., \& Miller, R. T. (2017). Emergent arguments: A functional approach to analyzing student challenges with the argument genre. Journal of Second Language Writing, 38, 42-55. https://doi. org/10.1016/j.jslw.2017.10.013

Ramírez Balderas, I., \& Guillén Cuamatzi, P. M. (2018). Self and peer correction to improve college students' writing skills. PROFILE: Issues in Teachers' Professional Development, 20(2), 179-194. https://doi. org/10.15446/profile.v20n2.67095
Renaud, S., Tannenbaum, E., \& Stantial, P. (2007). Student-centered teaching in large classes with limited resources. English Teaching Forum, 45(3), 12-18.

Research Connections. (2019). Descriptive Statistics. Retrieved from https://www.researchconnections.org/ childcare/datamethods/descriptivestats.jsp

Riley, P. (1997). The guru and the conjurer: aspects of counselling for self- access. In P. Benson, \& P. Voller (Eds.), Autonomy and independence in language learning (pp. 114-131). Longman. https://doi. org/10.4324/9781315842172-10

Rose, D. \& Martin, J. R. (2012). Learning to Write, Reading to Learn: genre, knowledge and pedagogy in the Sydney School. Equinox.

Sharma, Sohil. (2019, May). Descriptive Statistics. [Archived document]. Horizons Universiy, Paris, France. https://www.researchgate. net/publication/333220406_Descriptive_Statistics

Sultana, A. (2009). Peer correction in ESL classroom. BRAC University Journal, 6(1), 11-19.

Susanti, R., Deepali, M., \& Indawan. (2020). The effective feedback practices in a large EFL writing class in Indonesia. Talent Development \& Excellence, 12(2s), 920-932.

Tashakkori, A., \& Creswell, J. W. (2007). Editorial: The new era of mixed methods. Journal of Mixed Methods Research, 1(1), 3-7. https://doi. org/10.1177/2345678906293042

Troyan, F. J. (2016). Learning to mean in Spanish writing: A case study of a genre-based pedagogy for standards-based writing instruction. Foreign Language Annals, 49(2), 317-335. https://doi.org/10.1111/ flan. 12192

Uswar, Y. \& Andriani, N. (2019). EFL students' ability in writing reviews for a novel at a university in Medan. Studies in English Language and Education, 6. https://doi.org/300-308.10.24815/siele.v6i2.14784 


\section{Appendix A: Grading Rubric}

\begin{tabular}{|c|c|c|c|c|c|}
\hline CATEGORY & Meets expectation & $\begin{array}{l}\text { Meets most } \\
\text { expectations }\end{array}$ & $\begin{array}{c}\text { Meets minimal } \\
\text { expectations }\end{array}$ & $\begin{array}{c}\text { Below } \\
\text { Expectations }\end{array}$ & $\begin{array}{l}\text { Fails to meet } \\
\text { Expectations }\end{array}$ \\
\hline \multicolumn{6}{|l|}{ TASK ACHIEVEMENT } \\
\hline - Follows the rhetorical & There is a clear & There are & The topic & The topic & The topic \\
\hline structure for a Review. & purpose stated in the & appropriate topic & sentences & sentences need & sentences have to \\
\hline (Paragraph I: Description, & three topic sentences, & sentences and & and the text & some work, and & be restructured, \\
\hline paragraph 2: Positive features, & and the composition & the composition & components & the composition & and the \\
\hline paragraph 3: negative features & has all the required & has most of its & have some & sections must be & composition has \\
\hline and opinion). & components. & components. & inconsistencies. & completed. & to include various \\
\hline - The Topic Sentences in the 3 & 1.5 & & & & key components. \\
\hline paragraphs of the composition & & 1.25 & & 0.75 & 0.5 \\
\hline are stated. TS Paragraph I: & & & 1.0 & & \\
\hline \multicolumn{6}{|l|}{ Review's topic and purpose, ISs } \\
\hline \multicolumn{6}{|l|}{ Paragraphs 2 and 3 : included 2} \\
\hline \multicolumn{6}{|l|}{ features (positive and negative). } \\
\hline \multicolumn{6}{|l|}{ - Tone and word choice are } \\
\hline \multicolumn{6}{|l|}{ appropriate for the audience. } \\
\hline \multicolumn{6}{|l|}{ FOCUS: } \\
\hline - Stays on topic throughout the & Supporting ideas & Supporting & Supporting ideas & Supporting ideas & Supporting ideas \\
\hline entire piece. & keep a clear focus & ideas and topic & are somehow & need to be better & must be linked \\
\hline - The topic sentences and & that is totally & sentences are clear & connected to the & linked to the & to the focus and \\
\hline supporting ideas are clear and & connected to the & and sufficiently & topic sentences, & main topic of the & purpose of the \\
\hline \multirow[t]{5}{*}{ connected to maintain the focus. } & topic sentences and & connected to & the sections of & text and central & text. \\
\hline & the sections of the & maintain the focus. & the text and & topic. & \\
\hline & composition. & & the focus is lost & 0.5 & \\
\hline & 1.25 & 1.0 & sometimes. & & 0.25 \\
\hline & & & 0.75 & & \\
\hline \multirow{8}{*}{$\begin{array}{l}\text { TEXT RELEVANCE: } \\
\text { - Writing is profound and } \\
\text { detailed showing a deep } \\
\text { understanding of the topic. } \\
\text { - The composition reflects } \\
\text { knowledge and critical } \\
\text { thinking about the topic. }\end{array}$} & Provides clear & Provides & Provides & Needs to provide & Must provide \\
\hline & and detailed & understandable & some vague & more clear & clear \\
\hline & explanations to & explanations & explanations & explanations & explanations \\
\hline & demonstrate a depth & to demonstrate & demonstrating & to demonstrate & to show some \\
\hline & of understanding. & a depth of & lack of full & a better & understanding of \\
\hline & & understanding. & understanding. & understanding. & the task. \\
\hline & & & & 0.5 & \\
\hline & 1.25 & 1.0 & 0.75 & & 0.25 \\
\hline GENERAL LINGUISTIC & The variety and & The use of & The use of & Needs to include & Must include basic \\
\hline USAGE & correct use of & grammar, & grammar, & more advanced & and advanced \\
\hline - Grammar usage facilitates & grammar, vocabulary & vocabulary and & vocabulary and & language & language \\
\hline reading comprehension. & and mechanics enrich & mechanics keep & mechanics are & structures and & structures and \\
\hline - Vocabulary and connectors & the text. & overall readability. & sometimes faulty & vocabulary to & vocabulary to \\
\hline enrich the text. & & & and with some & support paper & make the paper \\
\hline - The use of mechanics & & & inconsistencies. & readability. & readable. \\
\hline patterns (spelling, punctuation, & & & & & 0.0 \\
\hline capitalization, paragraphing & 1.0 & & 0.5 & 0.25 & \\
\hline etc.) facilitates reading & & 0.75 & & & \\
\hline comprehension. & & & & & \\
\hline
\end{tabular}




\section{Appendix B: Online Survey}

For the following sentences, choose the option that best fits your experience of writing a review / Para las siguientes afirmaciones, escoje la opción que más se adapta a tu experiencia escribiendo un "review.

\begin{tabular}{ccccc}
\hline $\begin{array}{c}\text { Totally agree } / \\
\text { Totalmente de acuerdo }\end{array}$ & $\begin{array}{c}\text { Partially agree } / \\
\text { Parcialmente de acuerdo }\end{array}$ & $\begin{array}{c}\text { Neither agree nor disagree } / \\
\text { Ni de acuerdo ni en desacuerdo }\end{array}$ & $\begin{array}{c}\text { Disagree } / \\
\text { En desacuerdo }\end{array}$ & $\begin{array}{c}\text { Strongly disagree / } \\
\text { Totalmente en desacuerdo }\end{array}$ \\
\hline
\end{tabular}

Over the semester, my overall writing skills have improved/ A lo largo de este semestre, mis habilidades para escribir han mejorado.

The writing process helps construct the structure of the three paragraphs/ El proceso de escritura me ha ayudado a construir la estructura de los tres párrafos.

The writing process has helped me structure the language needed to evaluate a webpage or app/ El proceso de escritura me ha ayudado a estructurar el lenguaje requerido para evaluar una página web o aplicación

I understood the different sections of the review composition / Entendí las diferentes partes de una composición "review"

My classmate's feedback was crucial to my success / La realimentación de mi compañero fue crucial para el éxito de mi escrito

My teacher's feedback on the outline was crucial to my success / La realimentación de la profesora en el "outline" fue crucial para el éxito de mi escrito

Analyzing examples of other students' compositions (models in class) helped me understand the writing structure / Analizar ejemplos de composiciones hechas por otros estudiantes (modelos compartidos en clase) me ayudó a comprender la estructura del escrito

I am satisfied with my writing performance in the course / Estoy safisfecho con mi desempeño en el proceso de escritura de este curso

What I learned about writing in this class will help me in my future English classes / Los aprendizajes sobre escritura de este curso me ayudarán en mis futuras clases de inglés

What I learned about writing in this class will help me improve my writing in the classes I am taking towards my major (career) / Los aprendizajes sobre escritura de este curso me ayudarán a mejorar en otras clases de mi carrera.

Before taking this class, I had previous experience writing reviews in English / Antes de tomar esta clase había tenido experiencia escribiendo "reviews" en inglés.

Before taking this class, I had previous experience writing reviews in Spanish / Antes de tomar esta clase había tenido experiencia escribiendo "reviews" en español.

My ability to write reviews in English has improved since the beginning of this semester / Mi habilidad para escribir "reviews" ha mejorado en comparación con el inicio del semestre

\section{Open ended Questions:}

Which course activities helped you improve your writing? Why? / ¿Qué actividades de este curso te han ayudado a mejorar en tu habilidad de escritura? ¿Por qué?

What were some of the most challenging components of learning to write a review composition this semester? Why? / ¿Cuáles fueron los mayores retos en el proceso de escribir "reviews" este semestre?

What improvements do you feel could be implemented in the writing process of the English program? ¿¿Qué mejoras crees se pordrían implementar en el proceso de escritura del programa de Inglés? 


\section{Appendix C: Students' artifacts}

\section{Participant 27 (Grade 5,0)}

Spotify is one of the best apps that you can download if you love music. Spotify is a streaming service of music. It is used by people of all ages, also it is an app that people use to listen any kind of music and it has more services that you can enjoy. For that reason, Spotify is one of the most famous apps to listen to music.

This app has excellent features as download music and podcast service. At first, you can download songs that you love, that feature is so useful because when you do not have internet connection, you will never lack your favorite songs. Another good feature is the podcast service, when you are bored with the music, you can listen to podcasts, there are a lot of interesting podcast!, you can find on the podcast section any theme that you can imagine, you just have to search in your preferences. For those two and other features, a lot of people think Spotify is fantastic.

In contrast, Spotify has two big negatives features, as people have to pay to use it and your downloads are conditioned. Firstly, to use Spotify you have to pay between 12.000 and 16.000 Colombian pesos, it is so bad because there are a lot of people who do not like to pay for an app, and secondly, you just can listen to music downloaded if you have Spotify opened and if you are paying for it, because Spotify is a service. There are other apps that are free and you can download them, but they have a lot of advertisements and they are not personalized like Spotify. In my opinion, it is so useful for entertainment and it is the best app to listen to music.

\section{Participant 2 (Grade: 3,0)}

It is one of the best app about music is Spotify. It is use by many people in the world then is a music app meny famous because it has acces to different songs with a wide variety of artists, in addition, Spotify has different option where music app can be free or premium.

This music app has best because it is fantastic and useful. Fistly,Spotify has acces many songs of different musical genre and artists, therefore it is a music app with a lot of variety for all kind of people, thus being a music app fantastic, another good point is the possibility of use and create different playlist with variety of artists and save playlist the like. Spotify is perfect music app becausa it has different option so much for the songs how for use it.

On the other hand, there are also some problems with, it is advertisements and artists is missing. Fisrt of all that people uses the music app free or premiun, for example Spotify is free but it has advertising and if you want to remove the advertising, in addition you want to use it without internet you have to pay, the other negative point is that Spotify artists is missing the other countris not so well known or rare. In my opinion Spotify is a music app useful because it has different opntion the content and use.

\section{Appendix D: Focus Group}

1. Walk me through your experience learning how to write a review composition. Describe the elements of the writing process.

2. Describe the roles your classmates played in your writing process. What was positive about this and what was challenging? 
3. What are some of the strengths of the writing process taught in this class?

4. What were some of the challenges you faced learning to write a review composition in this class?

5. Did you learn any skills that you can you use in other areas of your academic and professional life?

6. What changes do you think your English teachers could make in the writing process to improve student success?

How to cite this article: Durán-Bautista, D. C. (2021). Fostering written production of review texts among EFL university students through a genre-based approach. Íkala, Revista de Lenguaje y Cultura, 26(1), 117-138. https://doi.org/10.17533/udea.ikala.v26n01a10 